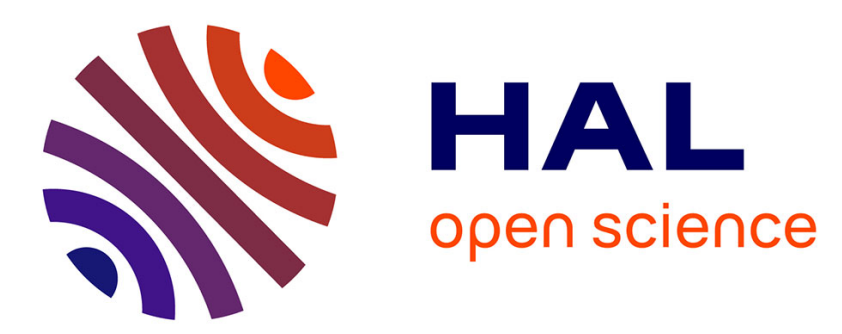

\title{
Influence of dams on river water-quality signatures at event and seasonal scales: The Sélune River (France) case study
}

Ophélie Fovet, Mamadou Ndom, Alain Crave, Alexandrine Pannard

\section{- To cite this version:}

Ophélie Fovet, Mamadou Ndom, Alain Crave, Alexandrine Pannard. Influence of dams on river waterquality signatures at event and seasonal scales: The Sélune River (France) case study. River Research and Applications, 2020, 36 (7), pp.1267-1278. 10.1002/rra.3618 . hal-03059914

HAL Id: hal-03059914

https://hal-univ-rennes1.archives-ouvertes.fr/hal-03059914

Submitted on 13 Dec 2020

HAL is a multi-disciplinary open access archive for the deposit and dissemination of scientific research documents, whether they are published or not. The documents may come from teaching and research institutions in France or abroad, or from public or private research centers.
L'archive ouverte pluridisciplinaire HAL, est destinée au dépôt et à la diffusion de documents scientifiques de niveau recherche, publiés ou non, émanant des établissements d'enseignement et de recherche français ou étrangers, des laboratoires publics ou privés. 
This is the peer reviewed version of the following article: Fovet, $O, N$ dom, $M$, Crave, $A$, Pannard, $A$. Influence of dams on river water-quality signatures at event and seasonal scales: The Sélune River (France) case study. River Res Applic. 2020; 36: 1267- 1278. https://doi.org/10.1002/rra.3618, which has been published in final form at https://doi.org/10.1002//ra.3618. This article may be used for non-commercial purposes in accordance with Wiley Terms and Conditions for Use of SelfArchived Versions.

\title{
Influence of dams on river water-quality signatures at event and seasonal scales: the Sélune River (France) case study
}

Running title: Influence of dams on seasonal and storm river-quality signatures

O. Fovet ${ }^{1 *}$, M. Ndom ${ }^{1}$, A. Crave ${ }^{2}$, A. Pannard ${ }^{3}$

${ }^{1}$ UMR SAS, INRAE, AGROCAMPUS OUEST, Rennes, France

${ }^{2}$ OSUR, Geosciences Rennes, Université de Rennes 1, CNRS, Campus de Beaulieu, Rennes, France

${ }^{3}$ OSUR, ECOBIO, Université de Rennes 1, CNRS, Campus de Beaulieu, Rennes, France

*Corresponding author: ophelie.fovet@inrae.fr

\section{Acknowledgment}

The Agence de l'Eau Seine Normandie funded the equipment and the analyses as well as the salary of Mamadou Ndom since 2016. Chemical analyses have been conducted by Béatrice Trinkler, INRA, UMR SAS, Rennes. We thanks Florent Michel, Ludovic Michel and Florian Boucard from EDF as well as Gilles Berrée from DDTM50 for providing data and information about the dams' management. We would like to thank Dr. Catherine Grimaldi, retired from INRA, UMR SAS, Rennes and Claude Legonidec who actively contributed to the project design and the data acquisition up to 2016.

\begin{abstract}
Dams and reservoirs are known to disturb river-water composition, among other impacts, with potential implications for downstream river ecosystems and water uses. Existing studies have emphasized the variable influence of dams on water composition according to the element, its speciation (dissolved vs. particulate), reservoir properties (residence times), reservoir functions (e.g. hydropower, irrigation), and management (water releases). A now common approach to analyzing hydrological, geochemical, and biological controls on element export from unregulated rivers is to study hydrochemical signatures such as concentration-flow relationships. We investigated a case study to analyze hydrochemical signatures of a regulated river (Sélune River, western France) upstream and downstream of a chain of two hydropower dams, assuming that the dams disturbed the river's signatures, and that those disturbances would provide information about processes occurring in the reservoirs. Both seasonal and event-scale signatures were analyzed over two contrasting hydrological years and a range of storm events. The dams
\end{abstract}


induced a chemostatic downstream response to storm events whenever elements were diluted or concentrated upstream. Dams did not disturb the seasonality of major anions but did modify silica and phosphorus concentration-flow relationships, especially during low flow. Such changes in dynamics of river-water composition may affect downstream biological communities. This study presents an initial state of the hydrochemical signature of the downstream river, before the removal of the two dams.

\section{Keywords}

Dams, river-water concentrations, hydrochemical signatures, anions, nutrients, suspended sediments

\section{Introduction}

Dams are a critical water infrastructure with social, economic, and environmental impacts that challenge the concept of sustainability (Moran, Lopez, Moore, Müller, \& Hyndman, 2018; Vedachalam \& Riha, 2013). In terms of environmental impacts, dams strongly alter river hydrological, sediment, hydrochemical, and biological connectivity and continuity (Bednarek, 2001; Kelly, 2001; Liro, 2019; Pestana, Azevedo, Bastos, \& Magalhães de Souza, 2019; Vörösmarty et al., 2003). In terms of water chemistry, dams and the reservoirs they form are known to disturb river-water composition (Aristi et al., 2014; Mantel, Hughes, \& Muller, 2010; Palmer \& Okeeffe, 1990; Pozo, Orive, Fraile, \& Basaguren, 1997; Van Cappellen \& Maavara, 2016) in the following ways:

1) Dams modify the flow regime in downstream reaches according to their management, and water chemical composition varies with flow (Carling et al., 2015; Chittoor Viswanathan, Molson, \& Schirmer, 2015; Graf, 2001).

2) Dams modify the chemical weathering rates which are controlled by residence times in watersheds (Brink, Humborg, Sahlberg, Rahm, \& Mörth, 2007; Gao et al., 2013).

3) Reservoirs are physical barriers known to trap suspended materials (Carling et al., 2015; Eiriksdottir, Oelkers, Hardardottir, \& Gislason, 2017) and likely to concentrate some solutes by evaporation (Kelly, 2001), but they are also biogeochemically reactive (Garnier, Leporcq, Sanchez, \& Philippon, 1999; Maavara, Dürr, \& Van Cappellen, 2014) and thus likely to affect nutrient cycles.

4) Reservoirs are also likely to modify exchanges between groundwater and the river by changing local piezometric gradients (Murgulet, Murgulet, Spalt, Douglas, \& Hay, 2016; Taleb et al., 2008)

Studies that investigated the influence of dams on water nutrients - nitrogen $(\mathrm{N})$, phosphorus $(\mathrm{P})$, carbon (C), and silica ( $\mathrm{Si}$ ) -concentrations (see review in Table 1) found that the influence varied according to the element, its speciation, reservoir properties, dam function and management. The downstream response partly depends on the biogeochemical and ecological functioning of lakes, controlled by their temperature and vertical mixing driven by wind and heat exchanges with the atmosphere (Spigel \& Imberger, 1987). Seasonal stratification often leads to late summer hypoxic deep waters, while sinking organic carbon originating from surface phytoplankton accumulates in the hypolimnion (Dodds \& Whiles, 2010), leading to sediment anoxic after a few millimeters. If so the trapping ability of sediment decreases and benthic fluxes increase (Wetzel, 2001) except if redox-insensitive P-binding systems, such as aluminium hydroxide, are present (Hupfer \& Lewandowski, 2008). Anoxic deepwater in lakes remobilizes phosphates, providing nutrients for phytoplankton by upwelling of deep water and internal waves (MacIntyre, Flynn, Jellison, \& Romero, 1999). The mixing regime in dams thus regulate the water quality downstream (Winton, Calamita, \& Wehrli, 2019). 
The typical approach for identifying the influence of dams on water chemistry is thus to compare concentrations or fluxes upstream and downstream of dams for periods ranging from one year to several decades. In contrast, export regime of dissolved or suspended element in unregulated rivers and streams are widely studied by analyzing water quality signatures such as concentration-flow (C-Q) relationships (Bieroza, Heathwaite, Bechmann, Kyllmar, \& Jordan, 2018; Bowes, House, Hodgkinson, \& Leach, 2005; Minaudo et al., 2019; Moatar, Abbott, Minaudo, Curie, \& Pinay, 2017; Musolff, Fleckenstein, Rao, \& Jawitz, 2017). Looking at the relative change in river-water concentrations as a function of flow allows for normalizing watershed behavior for several elements to compare either event behaviors (Bieroza \& Heathwaite, 2015; Bowes et al., 2005; Butturini, Alvarez, Bernal, Vazquez, \& Sabater, 2008; Evans \& Davies, 1998) or watersheds (Godsey, Kirchner, \& Clow, 2009; Musolff, Schmidt, Selle, \& Fleckenstein, 2015; Moatar et al., 2017; Rose, Karwan, \& Godsey, 2018). These relationships provide indications on elements source location, abundance or biogeochemical processes leading to their retention or transformation (Moatar et al., 2017).

Since dams can have major hydrological and biogeochemical impacts on downstream river reaches, one can assume the following:

1) Dams disturb hydrochemical signatures of rivers; thus, anyone seeking to use these signatures to infer watershed processes should carefully consider the role of any dams present.

2) Modification of these signatures by dams can provide information about the processes occurring in the reservoir-river system.

Therefore, we investigated a case study to analyze hydrochemical signatures of a regulated river (Sélune River, western France) upstream and downstream of a chain of two hydropower dams. The choice of the site was also motivated by the perspective of the two dams removal by 2021 . We selected the following signatures: the ratio of coefficients of variation $(\mathrm{CV})$ of $\mathrm{C}$ and $\mathrm{Q}$ (Thompson, Basu, Lascurain, Aubeneau, \& Rao, 2011), and the slope of the C-Q regression in the log domain (Godsey et al., 2009). We analyzed both seasonal and event-scale signatures over two hydrological years and for a range of events.

\section{Materials and methods}

\section{Study site}

The Sélune River drains a $1083 \mathrm{~km}^{2}$ watershed before flowing into Mont-Saint-Michel Bay (Fig. 1), in western France. The river is $91 \mathrm{~km}$ long and regulated by two hydroelectric dams, Vezin and La-Rochequi-Boit (36 and $16 \mathrm{~m}$ high, respectively). Climate is temperate and oceanic, with annual mean $( \pm 1$ standard deviation) precipitation as rainfall of $751 \mathrm{~mm} \pm 224 \mathrm{~mm}$ for the study period 2015-2018. Precipitation peaks in January $(109 \pm 51 \mathrm{~mm})$ and is lowest in July $(48 \pm 24 \mathrm{~mm})$. Because of seasonal variations in Potential Evapotranspiration, stream flow shows seasonal fluctuations: high flow period occurring in Winter and low flow period at the end of Summer (SI Fig. S1).

The bedrock is composed of granite in the north and south of the watershed, and of Brioverian schist in the middle. Because of the low permeability of the substratum, groundwater bodies are particularly shallow, leading to hydromorphic soils in bottomlands, while hillslopes have mainly well-drained Cambisols (USS Working Group WRB, 2006). Most slopes are moderate and less than 3\% but can reach $13 \%$ in the river gorge and in valleys of some tributaries. The watershed is dominated (94\%) by agriculture with mixed crop-livestock farming, leading to dominant grass and arable land-uses.

The general reservoirs characteristics are given in Table 2. The French government plans to remove these two dams on the Sélune River in 2021. This operation is associated with a 16-year 
multidisciplinary scientific program to evaluate dam removal as a tool for restoring aquatic ecosystems. In this context, a monitoring strategy has been developed to record water, suspended, and dissolved fluxes before, during, and after dam removal. This study focuses on two years of pre-removal observations.

\section{Data acquisition}

On the river, two stations (Fig. 1), one upstream and one downstream of both dams, were instrumented in 2015 with sensors for continuous monitoring (every $6 \mathrm{~min}$ to $1 \mathrm{~h}$ ) of river water level, temperature, electrical conductivity, and turbidity. Stream discharge was determined from water level using a rating curve established for each station specifically by the Regional Directorate for Environment (DREAL). The upstream station, Virey, is located $4.6 \mathrm{~km}$ upstream of the lotic-lentic transition zone, corresponding to a drainage area of $629 \mathrm{~km}^{2}$. This upstream station is equipped with sensors for monitoring dissolved oxygen and $\mathrm{pH}$. The downstream station, Signy, is located $4 \mathrm{~km}$ downstream of the downstream dam (la Roche-Qui-Boit), corresponding to a drainage area of $777 \mathrm{~km}^{2}$. The downstream station is equipped with a fluorescence probe (AlgaeTorch) to monitor chlorophyll a concentration continuously. In this study, we also used the dissolved oxygen recorded just downstream the dam of La-Roche-Qui-Boit.

River water was sampled every week at the upstream and downstream stations, and some storm events were also sampled at both stations using automatic samplers (ISCO). At each sampling, $500 \mathrm{~mL}$ of water was filtered at $0.45 \mu \mathrm{m}$, and then the suspended sediments (SS) collected were dried and weighed to determine their concentration. Another unfiltered sub-sample was used to determine TP colorimetrically by reaction with ammonium molybdate after mineralization with potassium peroxydisulfate. A third subsample was filtered at $0.45 \mu \mathrm{m}$ to determine major anion (chloride $(\mathrm{Cl}), \mathrm{NO}_{3}$, sulfate $\left(\mathrm{SO}_{4}\right)$ ) concentrations by ionic chromatography, and $\mathrm{PO}_{4}$ and dissolved $\mathrm{Si}$ by colorimetry based on reaction with ammonium molybdate (in acid conditions for $\mathrm{Si}$ ). For ca. half of the samples, a final sub-sample was filtered to determine $\mathrm{C}$ and $\mathrm{N}$ content of SS using an elemental analyzer (Thermo Finnigan CN FLASH EA 1112).

Vertical profiles of temperature, dissolved oxygen and fluorescence were measured monthly in 2015 and 2016 in the lakes using a multiparametric probe (Idronaut, OceanSeven 316Plus). Concentrations of $\mathrm{NO}_{3}$ and $\mathrm{PO}_{4}$ were measured as described above in $2 \mathrm{~L}$ of water sampled with a Niskin bottle at 3 depths ( $1 \mathrm{~m}$, euphotic zone, $1 \mathrm{~m}$ above the sediment).

\section{Signatures selected}

Signatures were analyzed separately for base-flow concentrations (obtained from regular weekly sampling) and storm-flow concentrations (obtained from automatic samplers). High and low base flows regimes were identified by dividing the hydrographs at each station by their respective median daily flow (SI Fig. S1) recorded over the period, following Moatar et al. (2017). Among the storm events sampled, we selected only those sampled at both stations (SI Fig. S5).

The ratio of coefficients of variation of $\mathrm{C}$ and $\mathrm{Q}\left(\mathrm{CV}_{\mathrm{C}}: \mathrm{CV}_{\mathrm{Q}}\right)$ was proposed by Thompson et al. (2011) as a characteristic of export regime. Ratios lower than 0.5 define chemostatic export regimes, indicating that element load variability is controlled by flow variability, while ratios greater than 0.5 qualify chemodynamic regimes. A chemostatic regime does not imply invariant concentration (Thompson et al., 2011). The non-linearity in C-Q relationships is usually accounted using a power law relationship (Godsey et al., 2009; Moatar et al., 2017; Musolff et al., 2015). This corresponds to a linear regression in log domain (Eq. 1). 


$$
\log (C)=a+b \log (Q)(1)
$$

Despite the large dispersion often observed in C-Q plots, this regression provides a simple metric to categorize C-Q in archetypes using the sign of exponent b (Musolff et al., 2017). We fitted the linear regressions using the least square method. Non-significant regression ( $p$-value $>0.005$ ) were classified as flat pattern, suggesting a uniform distribution of element, whereas significant regressions suggest more heterogeneous source in the catchment. Dilution patterns $(b<0)$ are associated to a control by element production or abundance. Enrichment patterns $(b>0)$ are rather controlled by transport capacity or flowpaths extension (Moatar et al., 2017). Biogeochemical reactions can enhance or attenuate these characteristics (Minaudo et al., 2019). The CV ratio and $b$ sign are not independent (Musolff et al., 2015) as strong enrichment or dilution cannot co-occur with very low CV ratios but flat pattern can be associated to high variance in concentrations leading to scattered C-Q plot, and CV ratios lower than 0.5 can coexist with weak dilution patterns (slightly negative $b$ values).

For event-scale, the dispersion in the C-Q relationships can also be related to hysteresis effects. Direction of hysteresis loops were also compared between the two stations and described as clockwise, anticlockwise or absent.

\section{Results}

\section{Reservoirs stratification}

Reservoirs undergo summer thermal stratification from mid-April to mid-October (Fig.2). Phytoplankton developed in the epilimnion of both reservoirs with summer concentrations fluctuating between 15 and $70 \mu \mathrm{g}$ chla $\mathrm{L}^{-1}$ (data not shown). Stratification was more stable in Vezins dam (twice deeper) than in Roche-qui-Boit (Fig. S9). The epilimnion in Vezins fluctuated between 4 and $5 \mathrm{~m}$ depth, with a thick metalimnion, and a hypolimnion at 11 to $13 \mathrm{~m}$ depth (Fig. 2). The turbine intakes (generally located at $6 \mathrm{~m}$ depth) thus drawed water from the top of the metalimnion in that reservoir. Roche-quiBoit was mainly stratified in July and August, with an epilimnion fluctuating between 5 and $7 \mathrm{~m}$ depth and a thermal gradient until the bottom of the lake, making the transition metalimnion to hypolimnion difficult to characterize. In both eutrophic reservoirs, bottom waters showed concentrations in oxygen below $1 \mathrm{mg} \mathrm{L}^{-1}$ in July and August, leading potentially to anaerobic conditions at the sediment-water interface. The hypolimnetic oxygen depletion coincided with a 52\% P enrichment in Vezins and a 120\% $\mathrm{P}$ enrichment in Roche-qui-Boit, compared with the epilimnion. It also coincided with a small vertical decrease in $\mathrm{NO}_{3}$ concentrations, but always remaining higher than $4 \mathrm{mg} \mathrm{N}-\mathrm{NO}_{3} \mathrm{~L}^{-1}$ in the hypolimnion (Table 2). A strong anoxia would have reduced these concentrations close to zero. Changes in nutrients concentrations associated with stratification thus remained limited here, all the more the turbine intakes never reached hypolimnetic anoxic waters.

\section{Seasonal variation in river base-flow concentrations}

Base-flow concentrations lay in the range of those previously observed in western France (Figs. S2-S3). The C-Q relationships were consistent between years at each station for a given flow regime (Fig. 3). CV ratios distinguished SS and Phosphorus (TP and SRP) with highly chemodynamic exports, and the dissolved elements with lower relative variance in their concentration (Table 3). The dams did not affect the export regimes excepted for Si during low flow that is observed to be more chemodynamic at the downstream station. 
Poorly significant regressions were usually associated with low C-Q slopes (median $|b|<0.1$ ) whereas significant regressions were associated to absolute slopes higher than 0.1 and high Pearson correlation coefficients: average $\left|\mathrm{r}_{\mathrm{P}}\right|$ of 0.6 (Table 3 ).

Enrichment patterns $(b>0)$ were associated to SS at the upstream station during high flow and to Phosphorus concentrations during low flow. Dilution patterns were observed for $\mathrm{Cl}$ for all stations and flow regimes, and for $\mathrm{NO}_{3}$ only during low flow and only significant at the upstream station. $\mathrm{SO}_{4}-\mathrm{Q}$ plots remained flat at both stations and whatever the flow regime. Dissolved Si showed an enrichment pattern at the downstream station reflecting the very low concentration occurring at low flow (Fig. S4) while Si-Q plots were flat at the upstream station. These C-Q patterns are consistent with the covariations observed in the time domain (Fig S4).

\section{Storm-flow responses}

As expected, storm-flow responses of each element's concentration varied among storms (SI Table S1, Fig S6-S8). Nevertheless, clear differences appeared between two groups: P and SS vs. anions and dissolved Si (Fig. 4).

$\mathrm{CV}$ ratios associated to storm-flow indicated that usually Phosphorus and SS concentrations at both stations were associated to the most chemodynamic storm export regimes (Table 4). Storm export regimes associated to dissolved anions and Silica are more chemostatic, and even more at the downstream station (SI Table S1).

For storm flow, poorly significant regressions were also usually associated with low C-Q slopes. Significant regressions were associated to high $\left|\mathrm{r}_{\mathrm{P}}\right|$ (Table S1): in average 0.85 (upstream) and 0.66 (downstream).

At the upstream station storms $\mathrm{TP}, \mathrm{PO}_{4}$ and $\mathrm{SS}$ were frequently associated to a strong enrichment patterns according to $\mathrm{C}$-Q slopes $>0.1$ while $\mathrm{Cl}, \mathrm{NO}_{3}, \mathrm{SO}_{4}$ and $\mathrm{Si}$ were usually associated to a dilution pattern (Table 4 and S1). On the contrary, at the downstream station, all storm C-Q were flat with unsignificant regressions or absolute slope close to zero.

For most events, the C-Q relationships exhibited hysteretic loops described by their direction (Table 4, and SI 2). For SS, TP, and $\mathrm{Cl}$ concentrations, most events exhibited a clockwise loop at the event scale at both stations, with both directions for $\mathrm{PO}_{4}$ at the downstream stations. $\mathrm{NO}_{3}$ and $\mathrm{SO}_{4}$ concentrations shifted from counter-clockwise loops upstream to clockwise loops downstream. Si exhibited both directions at the upstream station but mostly counter-clockwise loops at the downstream station.

\section{Discussion}

\section{Dams influence seasonal variations of TP and major anions less than the flow regime}

Highly chemodynamic export regimes have been reported for sediments and phosphorus concentrations in previous studies too (Moatar et al., 2017; Thompson et al., 2011). Thompson et al. (2011) suggested it can be related to heterogeneously distributed sources activation, threshold-driven transport mechanism (as bed load transport) and high reactivity of elements such as Phosphorus via sorption/desorption processes. The lower chemodynamism found for dissolved Si and anions was also expected from these previous studies and suggests that the dissolved element exported loads are mainly controlled by flow variability. It is usually related to the existence of large legacy storages, indeed emphasized in such 
agricultural contexts for $\mathrm{NO}_{3}$ (e.g. Howden, Burt, Worrall, Mathias, \& Whelan, 2011; Musolff et al., 2016) and $\mathrm{Cl}$ (Aubert et al., 2013; Hrachowitz, Fovet, Ruiz, \& Savenije, 2015).

At the upstream station, patterns observed for SS (flat in low flow, enrichment in high flow) are consistent with results from Moatar et al. (2017), and suggest an increased mobilization of sediment sources (soils or river bed) with transport capacity. The flatter SS-Q pattern at the downstream station reveals a disruption in sediment continuity along the river due to storage of particles in the reservoirs (Carling et al., 2015; Pozo et al., 1997). The difference of TP and $\mathrm{PO}_{4}-\mathrm{Q}$ pattern with enrichment limited to low flow could be explained by the relation between the phosphorus sorption capacity of the sediments and their size, e.g. (Landers \& Sturm, 2013). At low flow, mobilized SS would be finer and thus would have higher $\mathrm{P}$ content whereas during high flow the mobilization of bigger particles, with lower P content, would increase. Dams store sediments in the reservoirs but finest sediments (size $<10$ $\mu \mathrm{m})$, with negligible sedimentation rate and associated to high phosphorus content, cross the reservoirs.

In dams, seasonal stratification drives $\mathrm{P}$ release from sediment and oxygen depletion in hypolimnion (Hupfer et al. 2008). As turbine intakes occurred here at the top of the metalimnion, trapping efficiency of the dams increased and nutrients fluxes from hypolimnetic waters was limited. Consequently, for most major anions, the chemical composition of downstream water was little impacted by summer stratification. $\mathrm{Cl}$ is assumed non-reactive, its dilution pattern suggests a limited abundance of $\mathrm{Cl}$ in the catchment when water flow increase, as found by others (Godsey et al., 2009; Moatar et al., 2017). Previous authors found a dominance of $\mathrm{NO}_{3}$ enrichment pattern attributed to biological retention during low flows (Minaudo et al., 2019; Moatar et al., 2017) in contrast to the dilution pattern observed here. Despite its reactivity, $\mathrm{NO}_{3}$ behaved conservatively suggesting a moderate riverine biological effect on $\mathrm{NO}_{3}$ even at low flow. At the downstream station, the flatter pattern of $\mathrm{tNO}_{3}$ may express a moderate increase of biological $\mathrm{N}$ retention in the reservoirs. The seasonal variations of dissolved anions as a function of flow regime are not modified by the reservoirs (Fig. 3; Fig.S4).

\section{Retention and biogeochemical reactions affect $\mathrm{Si}$ and $\mathrm{PO}_{4}$ signatures mainly during low flow}

Chemostatic export regimes for Si observed at the upstream station are consistent with other findings (Godsey et al., 2009; Moatar et al., 2017) and can be attributed to higher weathering production rates when flow increases (Thompson et al., 2011). At the downstream station, higher chemodynamism and enrichment pattern indicate an increased biological retention or uptake of Si. Low flows co-occur with summer-autumn period, where light and temperature conditions are more favorable to phytoplankton growth in reservoirs, and particularly diatoms (Fig. 2, S9). The hypothesis of biological uptake during low flow was also supported by measured variations in temperature, dissolved oxygen concentration, and chlorophyll a concentration (Fig. 5).

The low flow enrichment pattern in $\mathrm{PO}_{4}$, flatter at the downstream station than at the upstream station, may also reflect an increased biological retention in the reservoirs through absorption by phytoplankton cells then incorporated in zooplankton and by sinking processes of both cells and feacal pellets (Lyche et al., 1996). At the bottom of lakes, P retention is counterbalanced by P release, associated with deeper microbial decomposition of organic matter and chemical dissolving process of sorbed $\mathrm{P}$ (Hupfer \& Lewandowski, 2008). The importance of a minimum hypolimnetic nitrate concentration here limits the accumulation of phosphates in the hypolimnion (Schauser, Chorus, \& Lewandowski, 2006). The biogeochemical reactivity of the dams remained limited here, excepting for the retention capacity, and downstream transfer of remobilized solutes is unlikely. 


\section{Damping storm flow by mixing and retention}

During storm events, concentration dynamics were consistently damped from the upstream to the downstream station whenever the upstream station had higher or lower solute concentrations.

Unsurprisingly, most SS, TP, and $\mathrm{PO}_{4}$ were highly exported during storm events associated with much higher concentrations than those during base flow (Jordan, Arnscheidt, McGrogan, \& McCormick, 2007). Highly chemodynamic regime and enrichment patterns reflect the processes of sediment mobilization from catchment soils by surface flowpaths and from river bed by transport capacity which are both increased during storms. Dominance of clockwise C-Q loops in such enrichment patterns suggest a depletion of particle sources leading to higher concentrations during rising limb than during the falling limb of the storm hydrograph as reported in a sub-basin of the Selune river (Dupas, GascuelOdoux, Gilliet, Grimaldi, \& Gruau, 2015; Vongvixay et al., 2018) and elsewhere (McDowell \& Sharpley, 2002; Seeger et al., 2004). The drastic decrease in SS, TP, and $\mathrm{PO}_{4}$ storm concentrations at the downstream station resulted from their storage in the reservoirs by deposition due to the decrease in flow velocity. Some of the SS and P measured at the downstream station may have come from the river bed itself. Indeed, the last reservoir and the downstream station are separated by $4 \mathrm{~km}$ of river, along which some fine sediments could remobilize during storm events.

The event dilution observed for $\mathrm{Cl}, \mathrm{SO}_{4}, \mathrm{NO}_{3}$, and $\mathrm{Si}$ at the upstream station reflects a limitation of these elements abundance despite the increase of water flow. The storm dilutions were not observed at the downstream station, due to mixing with the water volume of the reservoirs. The dominant hysteresis loop direction changed between upstream and downstream stations for biologically reactive solutes ( $\mathrm{Si}$, $\mathrm{NO}_{3}, \mathrm{SO}_{4}, \mathrm{PO}_{4}$ ) but not for conservative $\mathrm{Cl}$ (Table 4) suggesting that mixing is also affected by retention and release processes in the reservoirs water and sediments. Despite a management rule that aimed to mimic upstream flow variations at the outlet of the dams (Fig. S1), the dams completely filtered chemical signatures during storm events.

\section{Conclusion}

We used hydrochemical signatures usually applied to unregulated rivers to provide information about biological and hydrological controls on chemical elements exported by rivers, to analyze how dams influence these signatures. The analysis of the Sélune River case study confirmed the first hypothesis that dams modify these signatures at both seasonal and event scales. At the event scale, dams promote chemostaticity of the downstream river for all elements, whenever elements are diluted or concentrated during storm events upstream. For base flow, major anions and TP usually exhibited the same differences in their C-Q relationships between low and high flows at both stations, even though mean concentrations could differ between the two stations. This result suggests that the dams do not influence the processes controlling seasonal fluctuations of these elements. In contrast, $\mathrm{C}-\mathrm{Q}$ relationships for $\mathrm{Si}$ and $\mathrm{PO}_{4}$ differed between the stations, with larger differences during low flow. This alteration of river hydrochemical signatures reflects the biogeochemical processes that occur in the reservoirs themselves. Despite dam management designed to deliver an outflow similar to the inflow, our results show that the water released downstream of the dam has a different hydrochemical signature than natural river water, which may have potential effects on downstream biological communities.

Comparison of C-Q relationships instead of absolute concentrations appears valuable to help understand hydrological or biogeochemical processes altered by dams, supporting our second hypothesis. This highlights that the presence of reservoirs should be carefully considered when using such signatures to infer hydrological and biogeochemical processes in watersheds. 


\section{Data availability statement}

Upstream flow data and downstream dissolved oxygen data were provided by EDF. The other data, from the database of the Sélune Research Program, are available from the authors upon request.

\section{References}

Aristi, I., Arroita, M., Larranaga, A., Ponsati, L., Sabater, S., von Schiller, D., . . . Acuna, V. (2014). Flow regulation by dams affects ecosystem metabolism in Mediterranean rivers. Freshwater Biology, 59(9), 1816-1829. doi:10.1111/fwb.12385

Aubert, A. H., Gascuel-Odoux, C., Gruau, G., Akkal, N., Faucheux, M., Fauvel, Y., . . Merot, P. (2013). Solute transport dynamics in small, shallow groundwater-dominated agricultural catchments: insights from a high-frequency, multisolute 10 yr-long monitoring study. Hydrology and Earth System Sciences, 17(4), 1379-1391. doi:10.5194/hess-17-1379-2013

Bednarek, A. T. (2001). Undamming Rivers: A Review of the Ecological Impacts of Dam Removal. Environmental Management, 27(6), 803-814. doi:10.1007/s002670010189

Bieroza, M. Z., \& Heathwaite, A. L. (2015). Seasonal variation in phosphorus concentration-discharge hysteresis inferred from high-frequency in situ monitoring. Journal of Hydrology, 524(0), 333-347. doi:http://dx.doi.org/10.1016/j.jhydrol.2015.02.036

Bieroza, M. Z., Heathwaite, A. L., Bechmann, M., Kyllmar, K., \& Jordan, P. (2018). The concentration-discharge slope as a tool for water quality management. Science of the Total Environment, 630, 738-749. doi:https://doi.org/10.1016/j.scitotenv.2018.02.256

Bowes, M. J., House, W. A., Hodgkinson, R. A., \& Leach, D. V. (2005). Phosphorus-discharge hysteresis during storm events along a river catchment: the River Swale, UK. Water Research, 39(5), 751-762. doi:http://dx.doi.org/10.1016/j.watres.2004.11.027

Brink, J., Humborg, C., Sahlberg, J., Rahm, L., \& Mörth, C. M. (2007). Weathering rates and origin of inorganic carbon as influenced by river regulation in the boreal sub-arctic region of Sweden. Hydrol. Earth Syst. Sci. Discuss., 2007, 555-588. doi:10.5194/hessd-4-555-2007

Butturini, A., Alvarez, M., Bernal, S., Vazquez, E., \& Sabater, F. (2008). Diversity and temporal sequences of forms of DOC and NO3-discharge responses in an intermittent stream: Predictable or random succession? Journal of Geophysical Research-Biogeosciences, 113(G3). doi:10.1029/2008jg000721

Carling, G. T., Tingey, D. G., Fernandez, D. P., Nelson, S. T., Aanderud, Z. T., Goodsell, T. H., \& Chapman, T. R. (2015). Evaluating natural and anthropogenic trace element inputs along an alpine to urban gradient in the Provo River, Utah, USA. Applied Geochemistry, 63, 398-412. doi:10.1016/j.apgeochem.2015.10.005

Chittoor Viswanathan, V., Molson, J., \& Schirmer, M. (2015). Does river restoration affect diurnal and seasonal changes to surface water quality? A study along the Thur River, Switzerland. Science of the Total Environment, 532, 91-102. doi:http://dx.doi.org/10.1016/j.scitotenv.2015.05.121

Dodds, W. K., \& Whiles, M. R. (2010). Freshwater ecology: concepts and environmental applications of limnology: Elsevier Academic Press. 2nd edition.

Dupas, R., Gascuel-Odoux, C., Gilliet, N., Grimaldi, C., \& Gruau, G. (2015). Distinct export dynamics for dissolved and particulate phosphorus reveal independent transport mechanisms in an arable headwater catchment. Hydrological Processes, 29, 3162-3178. doi:10.1002/hyp.10432

Eiriksdottir, E. S., Oelkers, E. H., Hardardottir, J., \& Gislason, S. R. (2017). The impact of damming on riverine fluxes to the ocean: A case study from Eastern Iceland. Water Research, 113, 124-138. doi:10.1016/j.watres.2016.12.029

Evans, C., \& Davies, T. D. (1998). Causes of concentration/discharge hysteresis and its potential as a tool for analysis of episode hydrochemistry. Water Resources Research, 34(1), 129-137. doi:10.1029/97wr01881

Gao, Y., Wang, B., Liu, X., Wang, Y., Zhang, J., Jiang, Y., \& Wang, F. (2013). Impacts of river impoundment on the riverine water chemistry composition and their response to chemical weathering rate. Frontiers of Earth Science, 7(3), 351-360. doi:10.1007/s11707-013-0366-y

Garnier, J., Leporcq, B., Sanchez, N., \& Philippon. (1999). Biogeochemical mass-balances (C, N, P, Si) in three large reservoirs of the Seine basin (France). Biogeochemistry, 47(2), 119-146. doi:10.1007/bf00994919

Godsey, S. E., Kirchner, J. W., \& Clow, D. W. (2009). Concentration-discharge relationships reflect chemostatic characteristics of US catchments. Hydrological Processes, 23(13), 1844-1864. doi:10.1002/hyp.7315

Graf, W. L. (2001). Damage Control: Restoring the Physical Integrity of America's Rivers. Annals of the Association of American Geographers, 91(1), 1-27. doi:10.1111/0004-5608.00231 
Howden, N. J. K., Burt, T. P., Worrall, F., Mathias, S., \& Whelan, M. J. (2011). Nitrate pollution in intensively farmed regions: What are the prospects for sustaining high-quality groundwater? Water Resources Research, 47. doi:W00102 10.1029/2011wr010843

Hrachowitz, M., Fovet, O., Ruiz, L., \& Savenije, H. H. G. (2015). Transit time distributions, legacy contamination and variability in biogeochemical 1/f $\alpha$ scaling: how are hydrological response dynamics linked to water quality at the catchment scale? Hydrological Processes, 29(25), 5241-5256. doi:10.1002/hyp.10546

Hupfer, M., \& Lewandowski, J. (2008). Oxygen Controls the Phosphorus Release from Lake Sediments - a Long-Lasting Paradigm in Limnology. International Review of Hydrobiology, 93(4-5), 415-432. doi:10.1002/iroh.200711054

Jordan, P., Arnscheidt, A., McGrogan, H., \& McCormick, S. (2007). Characterising phosphorus transfers in rural catchments using a continuous bank-side analyser. Hydrol. Earth Syst. Sci., 11(1), 372-381. doi: $10.5194 /$ hess-11-372-2007

Kelly, V. J. (2001). Influence of reservoirs on solute transport: a regional-scale approach. Hydrological Processes, 15(7), 1227-1249. doi:10.1002/hyp.211

Landers, M. N., \& Sturm, T. W. (2013). Hysteresis in suspended sediment to turbidity relations due to changing particle size distributions. Water Resources Research, 49(9), 5487-5500. doi:10.1002/wrcr.20394

Liro M, (2019), Dam reservoir backwater as a field-scale laboratory of human-induced changes in river biogeomorphology: a review focused on gravel-bed rivers. Science of the total environment, (651) 28992912

Lyche, A., Andersen, T., Christoffersen, K., Hessen, D. O., Berger Hansen, P. H., \& Klysner, A. (1996). Mesocosm tracer studies. 1. Zooplankton as sources and sinks in the pelagic phosphorus cycle of a mesotrophic lake. Limnology and Oceanography, 41(3), 460-474. doi:10.4319/lo.1996.41.3.0460

Maavara, T., Dürr, H. H., \& Van Cappellen, P. (2014). Worldwide retention of nutrient silicon by river damming: From sparse data set to global estimate. Global Biogeochemical Cycles, 28(8), 842-855. doi:10.1002/2014gb004875

MacIntyre, S., Flynn, K. M., Jellison, R., \& Romero, J. R. (1999). Boundary mixing and nutrient fluxes in Mono Lake, California. Limnology and Oceanography, 44(3), 512-529. doi:10.4319/lo.1999.44.3.0512

Mantel, S. K., Hughes, D. A., \& Muller, N. W. J. (2010). Ecological impacts of small dams on South African rivers Part 1: Drivers of change - water quantity and quality. Water $\mathrm{Sa}$, 36(3), 351-360.

McDowell, R. W., \& Sharpley, A. N. (2002). The effect of antecedent moisture conditions on sediment and phosphorus loss during overland flow: Mahantango Creek catchment, Pennsylvania, USA. Hydrological Processes, 16(15), 3037-3050. doi:10.1002/hyp.1087

Minaudo, C., Dupas, R., Gascuel-Odoux, C., Roubeix, V., Danis, P.-A., \& Moatar, F. (2019). Seasonal and eventbased concentration-discharge relationships to identify catchment controls on nutrient export regimes. Advances in Water Resources, 131, 103379. doi:https://doi.org/10.1016/j.advwatres.2019.103379

Moatar, F., Abbott, B. W., Minaudo, C., Curie, F., \& Pinay, G. (2017). Elemental properties, hydrology, and biology interact to shape concentration-discharge curves for carbon, nutrients, sediment, and major ions. Water Resources Research, 53(2), 1270-1287. doi:doi:10.1002/2016WR019635

Moran, E. F., Lopez, M. C., Moore, N., Müller, N., \& Hyndman, D. W. (2018). Sustainable hydropower in the 21st century. Proceedings of the National Academy of Sciences, 115(47), 11891. doi:10.1073/pnas.1809426115

Murgulet, D., Murgulet, V., Spalt, N., Douglas, A., \& Hay, R. G. (2016). Impact of hydrological alterations on river-groundwater exchange and water quality in a semi-arid area: Nueces River, Texas. Science of the Total Environment, 572, 595-607. doi:10.1016/j.scitotenv.2016.07.198

Musolff, A., Fleckenstein, J. H., Rao, P. S. C., \& Jawitz, J. W. (2017). Emergent archetype patterns of coupled hydrologic and biogeochemical responses in catchments. Geophysical Research Letters, 44(9), 41434151. doi:10.1002/2017g1072630

Musolff, A., Schmidt, C., Rode, M., Lischeid, G., Weise, S. M., \& Fleckenstein, J. H. (2016). Groundwater head controls nitrate export from an agricultural lowland catchment. Advances in Water Resources, 96, 95107. doi:http://dx.doi.org/10.1016/j.advwatres.2016.07.003

Musolff, A., Schmidt, C., Selle, B., \& Fleckenstein, J. H. (2015). Catchment controls on solute export. Advances in Water Resources, 86, 133-146. doi:https://doi.org/10.1016/j.advwatres.2015.09.026

Palmer, R. W., \& Okeeffe, J. H. (1990). Downstream effects of impoundments on the water chemistry of the buffalo river (Eastern Cape), South-Africa Hydrobiologia, 202(1-2), 71-83.

Pestana I, Azevedo L, Bastos W, Magalhães de Souza CM,. (2019). The impact of hydroelectric dams on mercury dynamics in South America: A review. Chemosphere, (219), 546-556

Pozo, J., Orive, E., Fraile, H., \& Basaguren, A. (1997). Effects of the Cernadilla-Valparaiso reservoir system on the River Tera. Regulated Rivers-Research \& Management, 13(1), 57-73. 
Rose, L. A., Karwan, D. L., \& Godsey, S. E. (2018). Concentration-discharge relationships describe solute and sediment mobilization, reaction, and transport at event and longer timescales. Hydrological Processes, 32(18), 2829-2844. doi:doi:10.1002/hyp.13235

Schauser, I., Chorus, I., \& Lewandowski, J. (2006). Effects of nitrate on phosphorus release: comparison of two Berlin lakes. Acta hydrochimica et hydrobiologica, 34(4), 325-332. doi:10.1002/aheh.200500632

Seeger, M., Errea, M. P., Beguería, S., Arnáez, J., Martí, C., \& García-Ruiz, J. M. (2004). Catchment soil moisture and rainfall characteristics as determinant factors for discharge/suspended sediment hysteretic loops in a small headwater catchment in the Spanish pyrenees. Journal of Hydrology, 288(3), 299-311. doi:https://doi.org/10.1016/j.jhydrol.2003.10.012

Spigel, R. H., \& Imberger, J. (1987). Mixing processes relevant to phytoplankton dynamics in lakes. New Zealand Journal of Marine and Freshwater Research, 21(3), 361-377. doi:10.1080/00288330.1987.9516233

Taleb, A., Belaidi, N., Sanchez-Perez, J. M., Vervier, P., Sauvage, S., \& Gagneur, J. (2008). The role of the hyporheic zone in the nitrogen dynamics of a semi-arid gravel bed stream located downstream of a heavily polluted reservoir (Tafna Wadi, Algeria). River Research and Applications, 24(2), 183-196. doi:10.1002/rra.1039

Thompson, S. E., Basu, N. B., Lascurain, J., Aubeneau, A., \& Rao, P. S. C. (2011). Relative dominance of hydrologic versus biogeochemical factors on solute export across impact gradients. Water Resources Research, 47. doi:W00j05 10.1029/2010wr009605

Van Cappellen, P., \& Maavara, T. (2016). Rivers in the Anthropocene: Global scale modifications of riverine nutrient fluxes by damming. Ecohydrology \& Hydrobiology, 16(2), 106-111. doi:https://doi.org/10.1016/j.ecohyd.2016.04.001

Vedachalam, S., \& Riha, S. J. (2013). Small is beautiful? State of the dams and management implications for the future. River Research and Applications, 30, 1195-1205. doi:10.1002/rra.2698

Vongvixay, A., Grimaldi, C., Dupas, R., Fovet, O., Birgand, F., Gilliet, N., \& Gascuel-Odoux, C. (2018). Contrasting suspended sediment export in two small agricultural catchments: Cross-influence of hydrological behaviour and landscape degradation or stream bank management. Land Degradation \& Development, 29(5), 1385-1396. doi:doi:10.1002/ldr.2940

Vörösmarty C.,Meybeck M., Fekete B., Sharma K., Green P., Syvitski JPM, (2003). Anthropogenic sediment retention: major global impact from registred river impoudments. Global Planetary Change, Vol 39, 169190.

Wetzel, R. G. (2001). Limnology: lake and river ecosystems: Elsevier Academic Press.

Winton, R. S., Calamita, E., \& Wehrli, B. (2019). Reviews and syntheses: Dams, water quality and tropical reservoir stratification. Biogeosciences, 16(8), 1657-1671. doi:10.5194/bg-16-1657-2019 
Table 1. Summary of case studies that investigated the influence of dams on water chemical concentrations.

\begin{tabular}{|c|c|c|c|}
\hline Location & Parameters & Response & Source \\
\hline Tera River (Spain) & $\begin{array}{l}\mathrm{Si}, \mathrm{NO}_{3}, \mathrm{PO}_{4}, \mathrm{TP} \\
\mathrm{NH}_{4}\end{array}$ & $\begin{array}{l}\text { High retention } \\
\text { Hypolimnetic release } \\
3 \mathrm{~km} \text { to } 10 \mathrm{~km} \\
\end{array}$ & Pozo et al. (1997) \\
\hline $\begin{array}{c}\text { Buffalo River (South } \\
\text { Africa) }\end{array}$ & $\mathrm{PO}_{4}, \mathrm{NO}_{3}$ & Shorter during low flow & $\begin{array}{c}\text { Palmer and Okeeffe } \\
(1990)\end{array}$ \\
\hline Tafna River (Algeria) & $\begin{array}{l}\text { organic matter, } \\
\mathrm{NH}_{4}\end{array}$ & $\begin{array}{c}\text { Retention through deposition } \\
\text { Release } \\
\text { High flow dilution/ low flow enrichment }\end{array}$ & $\begin{array}{l}\text { Taleb, Belaidi, and } \\
\text { Gagneur (2004) }\end{array}$ \\
\hline $\begin{array}{c}130 \text { agricultural } \\
\text { watersheds (Iowa, USA) }\end{array}$ & $\mathrm{NO}_{3}$ & $\begin{array}{c}\text { No retention in reservoirs dominated by } \\
\text { cyanobacteria } \\
\text { Slight decrease when reservoir residence times } \\
\text { were sufficient }\end{array}$ & $\begin{array}{l}\text { Downing, Cherrier, } \\
\text { and Fulweiler } \\
(2016)\end{array}$ \\
\hline Provo River (Utah, USA) & $\begin{array}{l}\text { trace-element } \\
\text { isotopic ratios }\end{array}$ & $\begin{array}{l}\text { Lower temporal variability, due to settling of } \\
\text { particle-attached elements and homogenization }\end{array}$ & Carling et al. (2015) \\
\hline Glacial river (Iceland) & annual elemental & $\begin{array}{l}\text { Retention of most particulate fluxes and release of } \\
\text { most dissolved fluxes }\end{array}$ & $\begin{array}{l}\text { Eiriksdottir et al. } \\
(2017)\end{array}$ \\
\hline Yangtze River (China) & major ions & $\begin{array}{l}\text { Increase in all major ion concentrations following } \\
\text { establishment of the reservoir }\end{array}$ & Wang et al. (2018) \\
\hline $\begin{array}{l}\text { Rio Grande and Colorado } \\
\text { basins (USA) }\end{array}$ & $\begin{array}{l}\mathrm{P} \\
\mathrm{NO}_{3} \\
\end{array}$ & $\begin{array}{c}\text { Retention } \\
\text { Decrease or increase depending on watershed }\end{array}$ & Kelly (2001) \\
\hline $\begin{array}{l}20 \text { reservoirs across the } \\
\text { world }\end{array}$ & $\mathrm{Si}$ & Retention of the global reactive Si load & $\begin{array}{l}\text { Maavara et al., } \\
\quad(2014)\end{array}$ \\
\hline
\end{tabular}


Table 2. Morphological and chemical characteristics of the two dams (year of build is given in parenthesis).

\begin{tabular}{ccc}
\hline Parameters & Dam of Vezins (1932) & Dam of Roche-qui-Boit (1919) \\
\hline Surface area $\left(\mathrm{km}^{2}\right)$ & 1.7 & 0.29 \\
Maximum volume $\left(\mathrm{m}^{3}\right)$ & 18000000 & 90000 \\
Maximum depth $(\mathrm{m})$ & 31 & 16 \\
Mean depth $(\mathrm{m})$ & 12 & 3.1 \\
Mean residence time (days) & 14 days (from Nov. to Apr.) & 1 day (from Nov. to Apr.) \\
& 47 days (from Jun. to Sept.) & 4 days (from Jun. to Sept.) \\
Summer concentrations & & \\
(mean \pm standard deviation): & $7.4 \pm 2.7$ & $7.4 \pm 3.0$ \\
Phosphates at surface $\left.(\mu \mathrm{g} \mathrm{P} \mathrm{L})^{-1}\right)$ & $11.3 \pm 3.6$ & $16.5 \pm 7.3$ \\
Phosphates at bottom $\left(\mu \mathrm{g} \mathrm{P} \mathrm{L}^{-1}\right)$ & $4.9 \pm 2.3$ & $5.3 \pm 1.3$ \\
Nitrates at surface $\left(\mathrm{mg} \mathrm{N} \mathrm{L}^{-1}\right)$ & $4.0 \pm 2.0$ & $4.6 \pm 2.0$ \\
Nitrates at bottom $\left(\mathrm{mg} \mathrm{N} \mathrm{L}^{-1}\right)$ & &
\end{tabular}


Table 3. Descriptors of the concentration (C) - flow (Q) relationship (U)pstream and (D)ownstream: the ratio of coefficients of variation $(\mathrm{CV})$ of $\mathrm{C}$ and $\mathrm{Q}$; the slope $(b)$ of the adjusted regressions between $\mathrm{C}$ and $\mathrm{Q}(\log (C)=a+b \log (Q))$; associated $\mathrm{p}$-value of the regressions (bold slopes values are associated to significant regression) and Pearson correlation coefficient $r_{P}$ between log transformed $C$ and Q.TP $=$ total phosphorus, $\mathrm{SS}=$ suspended sediments.

\begin{tabular}{|c|c|c|c|c|c|c|c|c|c|}
\hline Descriptor & Location & Flow & $\mathrm{Cl}$ & $\mathrm{NO}_{3}$ & $\mathrm{SO}_{4}$ & $\mathrm{Si}$ & $\mathrm{TP}$ & $\mathrm{PO}_{4}$ & SS \\
\hline \multirow{4}{*}{$\mathrm{CV}_{\mathrm{C}}: \mathrm{CV}_{\mathrm{Q}}$ ratio } & \multirow{2}{*}{$\mathrm{U}$} & low & 0,34 & 0,31 & 0,48 & 0,21 & $\mathbf{0 , 8 2}$ & 1,21 & 1,17 \\
\hline & & high & 0,22 & 0,21 & 0,16 & 0,13 & 1,19 & 0,61 & 0,76 \\
\hline & \multirow{2}{*}{$\mathrm{D}$} & low & 0,38 & 0,38 & 0,45 & 0,62 & 1,61 & 1,97 & 2,52 \\
\hline & & high & 0,32 & 0,35 & 0,28 & 0,26 & 1,18 & 1,41 & 1,67 \\
\hline \multirow{4}{*}{$\begin{array}{c}\text { slope of } \\
\log (C)-\log (Q)\end{array}$} & \multirow{2}{*}{$\mathrm{U}$} & low & $-0,25$ & $-0,17$ & 0,07 & $-0,07$ & 0,49 & 1,04 & 0,43 \\
\hline & & high & $-0,24$ & 0,04 & 0,02 & 0,00 & 0,39 & $-0,10$ & 0,56 \\
\hline & \multirow{2}{*}{$\mathrm{D}$} & low & $-0,15$ & $-0,14$ & 0,18 & $\mathbf{0 , 3 3}$ & 1,09 & $\mathbf{0 , 8 8}$ & 0,57 \\
\hline & & high & $-0,22$ & 0,09 & $-0,09$ & 0,17 & 0,39 & 0,64 & 1,06 \\
\hline \multirow{4}{*}{ p-value } & \multirow{2}{*}{$\mathrm{U}$} & low & 0,0000 & 0,0060 & 0,4370 & 0,1360 & 0,0130 & 0,0010 & 0,0870 \\
\hline & & high & 0,0000 & 0,5400 & 0,5940 & 0,9000 & 0,1040 & 0,6440 & 0,0068 \\
\hline & \multirow{2}{*}{$\mathrm{D}$} & low & 0,0470 & 0,0800 & 0,0580 & 0,0150 & 0,0013 & 0,0190 & 0,3080 \\
\hline & & high & 0,0100 & 0,4030 & 0,2430 & 0,0120 & 0,2890 & 0,0780 & 0,0620 \\
\hline \multirow{4}{*}{ rp. } & \multirow{2}{*}{$\mathrm{U}$} & low & $-0,80$ & $-0,57$ & 0,17 & $-0,34$ & 0,53 & 0,65 & 0,38 \\
\hline & & high & $-0,89$ & 0,13 & 0,12 & 0,03 & 0,36 & $-0,11$ & 0,57 \\
\hline & \multirow{2}{*}{$\mathrm{D}$} & low & $-0,40$ & $-0,35$ & 0,38 & 0,48 & 0,60 & 0,47 & 0,22 \\
\hline & & high & $-0,65$ & 0,24 & $-0,33$ & 0,63 & 0,29 & 0,46 & 0,53 \\
\hline
\end{tabular}


Table 4. Mean and standard deviations (sd) of descriptors of the concentration (C) - flow (Q) relationship for eight storm events (U)pstream and (D)ownstream: the ratio of coefficients of variation $(\mathrm{CV})$ of $\mathrm{C}$ and $\mathrm{Q}$; the slope $(b)$ of the significant adjusted regressions (p-value $\leq 0.05$ ) between $\mathrm{C}$ and $\mathrm{Q}(\log (C)=a+b \log (Q))$. Number of events exhibiting a clockwise $(\mathrm{Cw})$ or counter-clockwise $(\mathrm{CCw})$ direction when concentration-flow relationships show an identifiable loop for each parameter at (U)pstream or (D)ownstream stations. Event values of the descriptors are provided in SI (Table S1 $\& \mathrm{~S} 2) . \mathrm{TP}=$ total phosphorus, $\mathrm{SS}=$ suspended sediments.

\begin{tabular}{|c|c|c|c|c|c|c|c|c|c|}
\hline Descr. & station & & $\mathrm{Cl}$ & $\mathrm{NO}_{3}$ & $\mathrm{SO}_{4}$ & $\mathbf{S i}$ & TP & $\mathrm{PO}_{4}$ & SS \\
\hline \multirow{4}{*}{ CVc:CVQ } & $\mathrm{U}$ & mean & 0,33 & 0,55 & 0,43 & 0,46 & 1,77 & 1,00 & 3,13 \\
\hline & \multirow{3}{*}{$\mathrm{D}$} & sd & 0,13 & 0,33 & 0,15 & 0,22 & 0,57 & 0,40 & 1,47 \\
\hline & & mean & 0,21 & 0,09 & 0,05 & 0,21 & 1,26 & 1,91 & 2,18 \\
\hline & & sd & 0,33 & 0,09 & 0,03 & 0,22 & 0,98 & 1,40 & 1,22 \\
\hline \multirow{4}{*}{$\begin{array}{l}\text { slope of } \\
\text { significant C-Q } \\
\text { regressions }\end{array}$} & $\mathrm{U}$ & mean & $-0,35$ & $-0,59$ & $-0,13$ & $-0,42$ & 1,47 & 1,18 & 1,16 \\
\hline & \multirow{3}{*}{$\mathrm{D}$} & sd & 0,07 & 0,23 & 0,40 & 0,09 & 0,44 & - & 2,08 \\
\hline & & mean & - & $-0,03$ & $-0,01$ & - & - & - & - \\
\hline & & sd & - & - & 0,05 & - & - & - & - \\
\hline \multirow{2}{*}{$\mathrm{Cw}$ events } & $\mathrm{U}$ & number & 2 & 1 & 0 & 2 & 3 & 5 & 4 \\
\hline & $\mathrm{D}$ & number & 4 & 3 & 3 & 1 & 3 & 2 & 4 \\
\hline \multirow{2}{*}{$\mathrm{CCw}$ events } & $\mathrm{U}$ & number & 1 & 2 & 3 & 2 & 1 & 0 & 0 \\
\hline & $\mathrm{D}$ & number & 0 & 1 & 1 & 2 & 0 & 2 & 0 \\
\hline
\end{tabular}




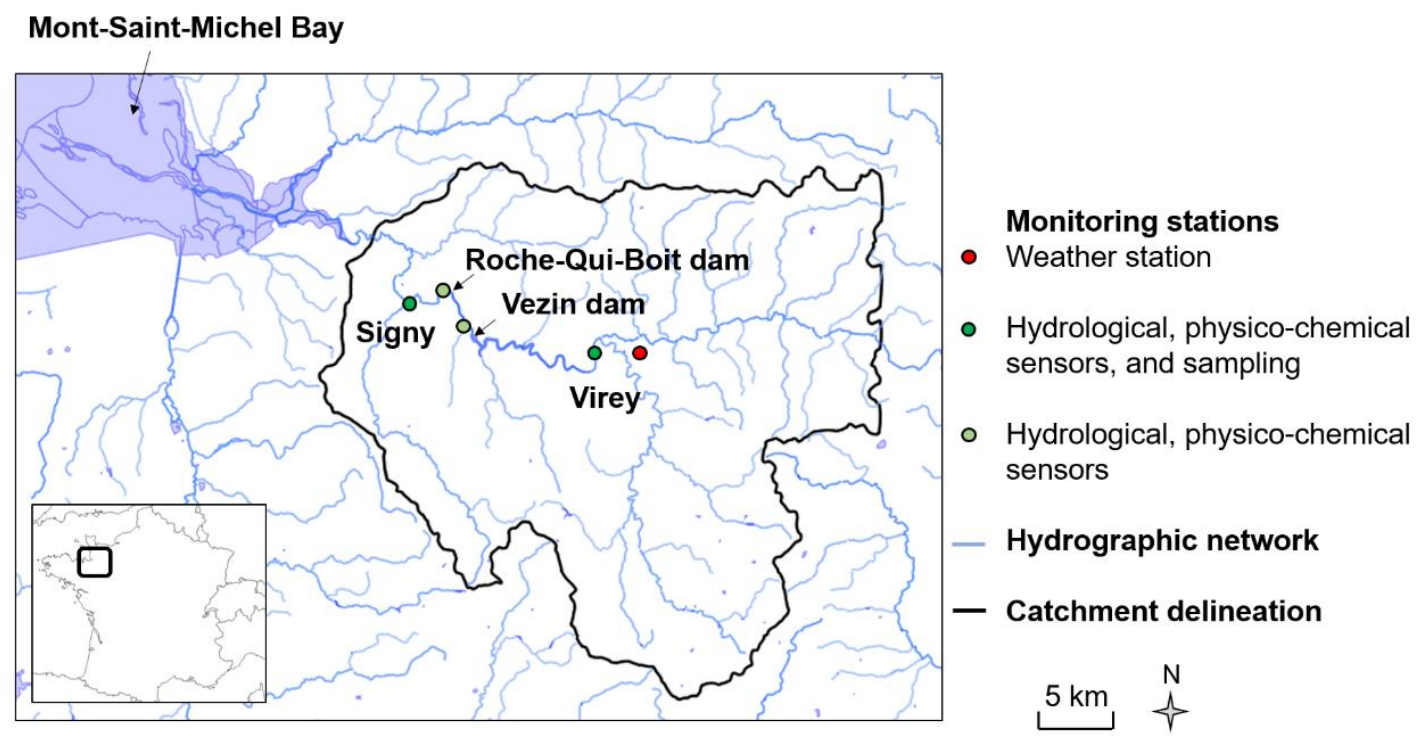

Figure 1. Map of the study site and locations of stations 

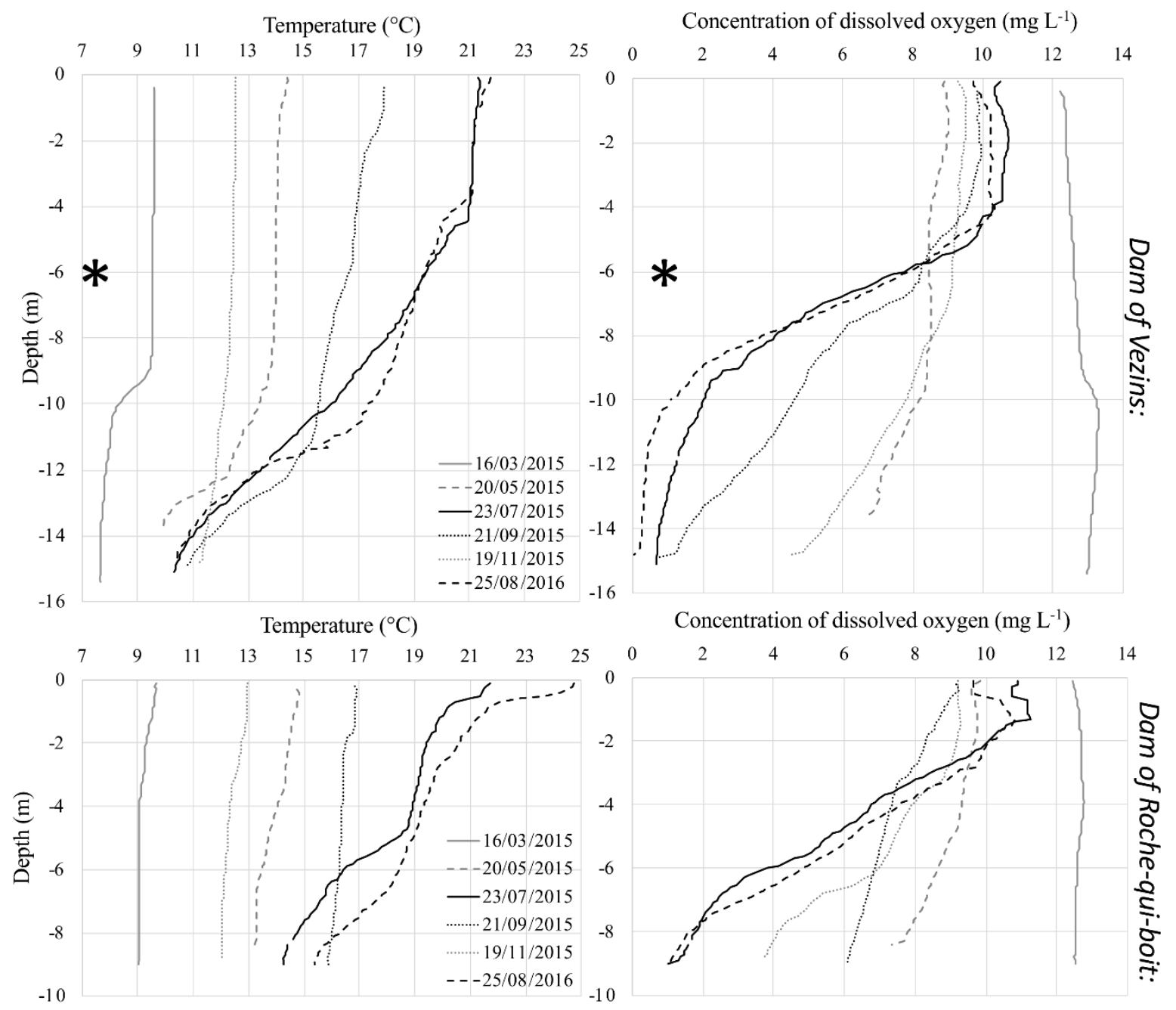

Figure 2. Profiles of temperature (left) and oxygen concentration (right), showing summer stratification in Vezins (top) and Roche-qui-boit dams (bottom), depending on dates. The black curves show summer profiles. The star shows the depth of the turbine intake to within $20 \mathrm{~cm}$. 

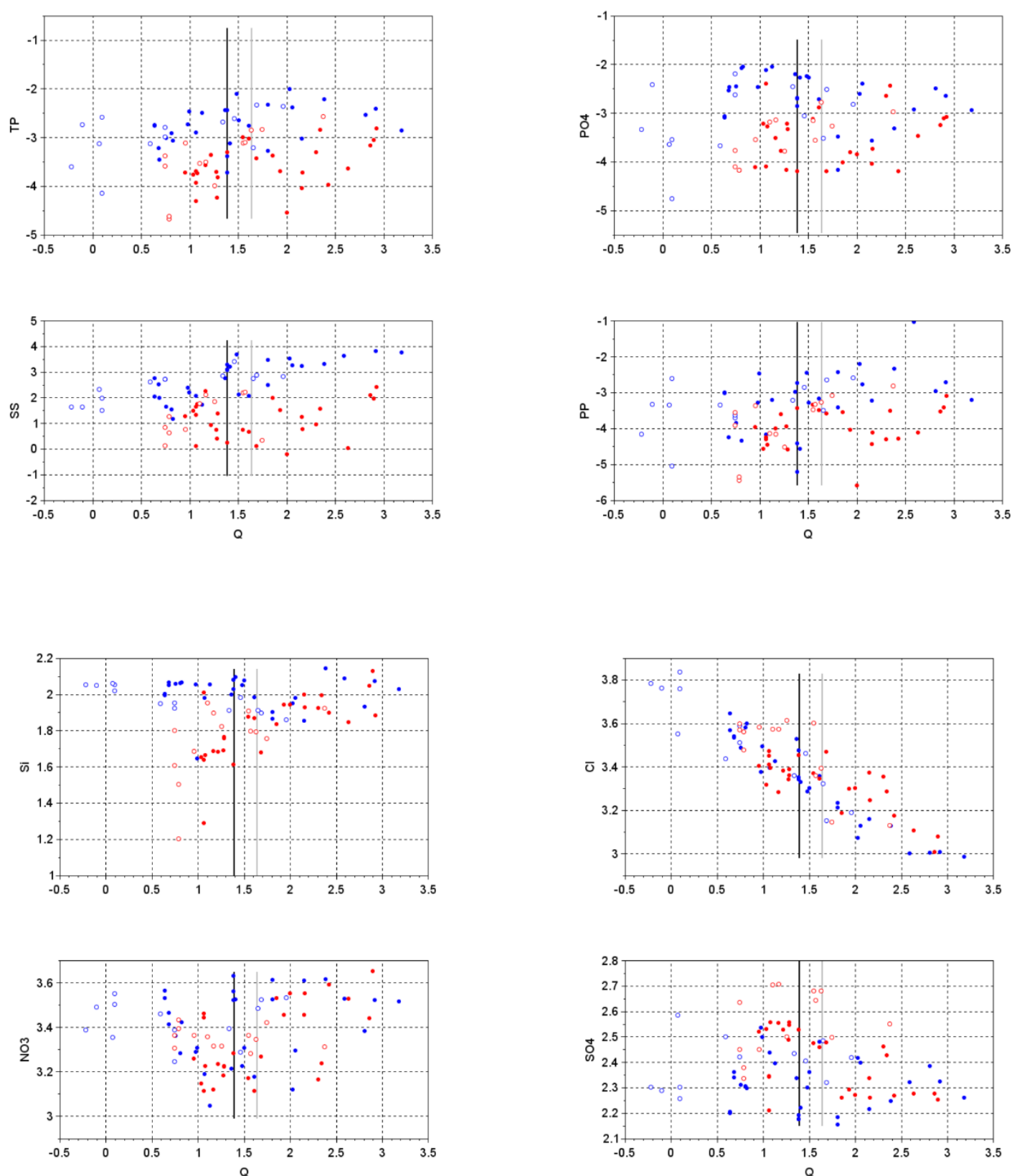

Figure 3. Concentration-flow relationships at upstream (blue) and downstream (red) stations in 20152016 (solid circles) and 2016-2017 (open circles) from weekly sampling. Both scales are plotted in log. Vertical lines indicate median daily flow at the upstream (black) and downstream (gray) station. 

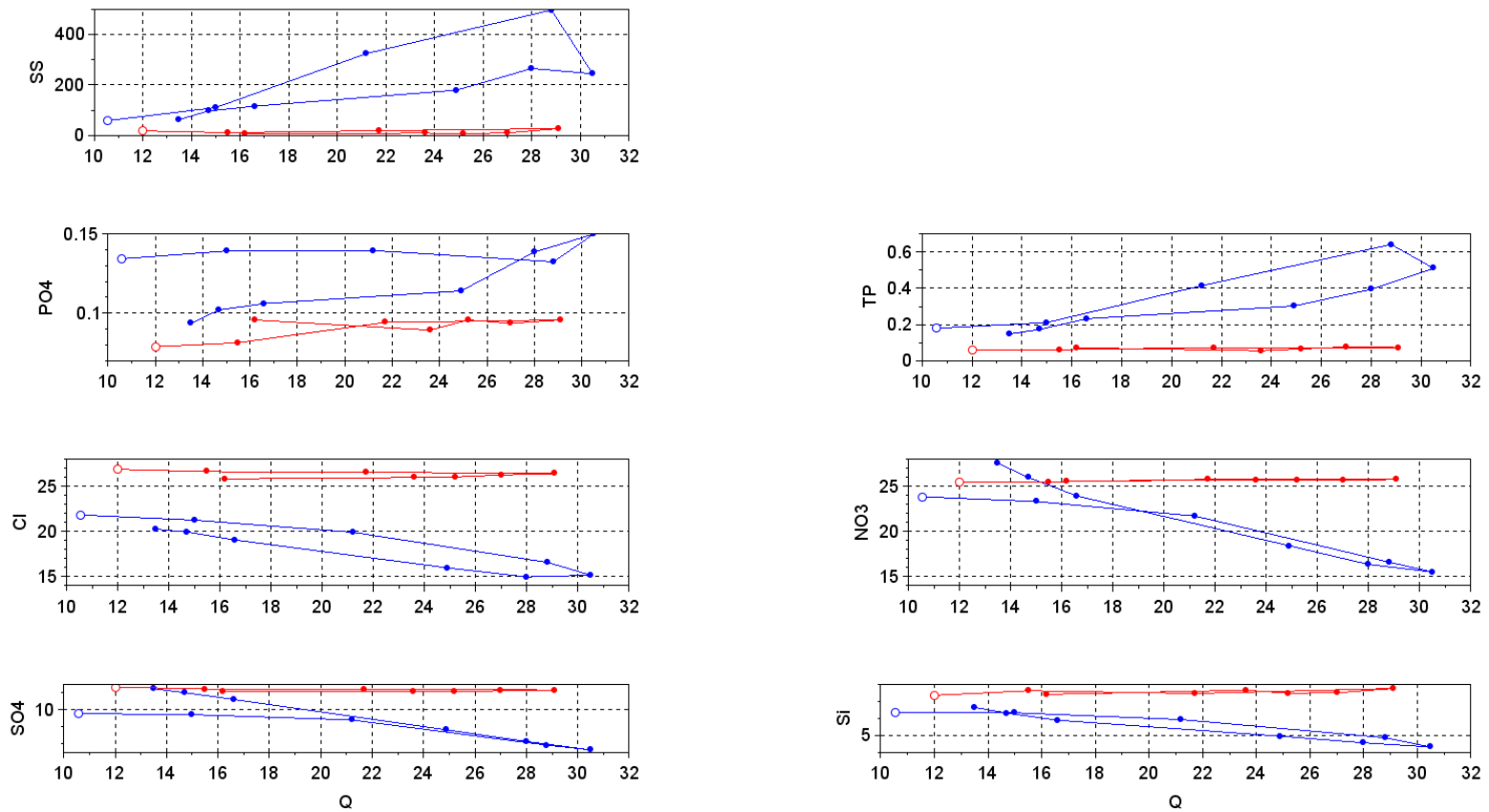

Figure 4. Concentration-flow relationships during storm event 1 at the upstream (blue) and downstream (red) station for each element. White circles identify the first sample of the event. Flow is expressed in $\mathrm{m}^{3} \mathrm{~s}^{-1}$, while concentrations are expressed in $\mathrm{mg} \cdot \mathrm{L}^{-1}$.
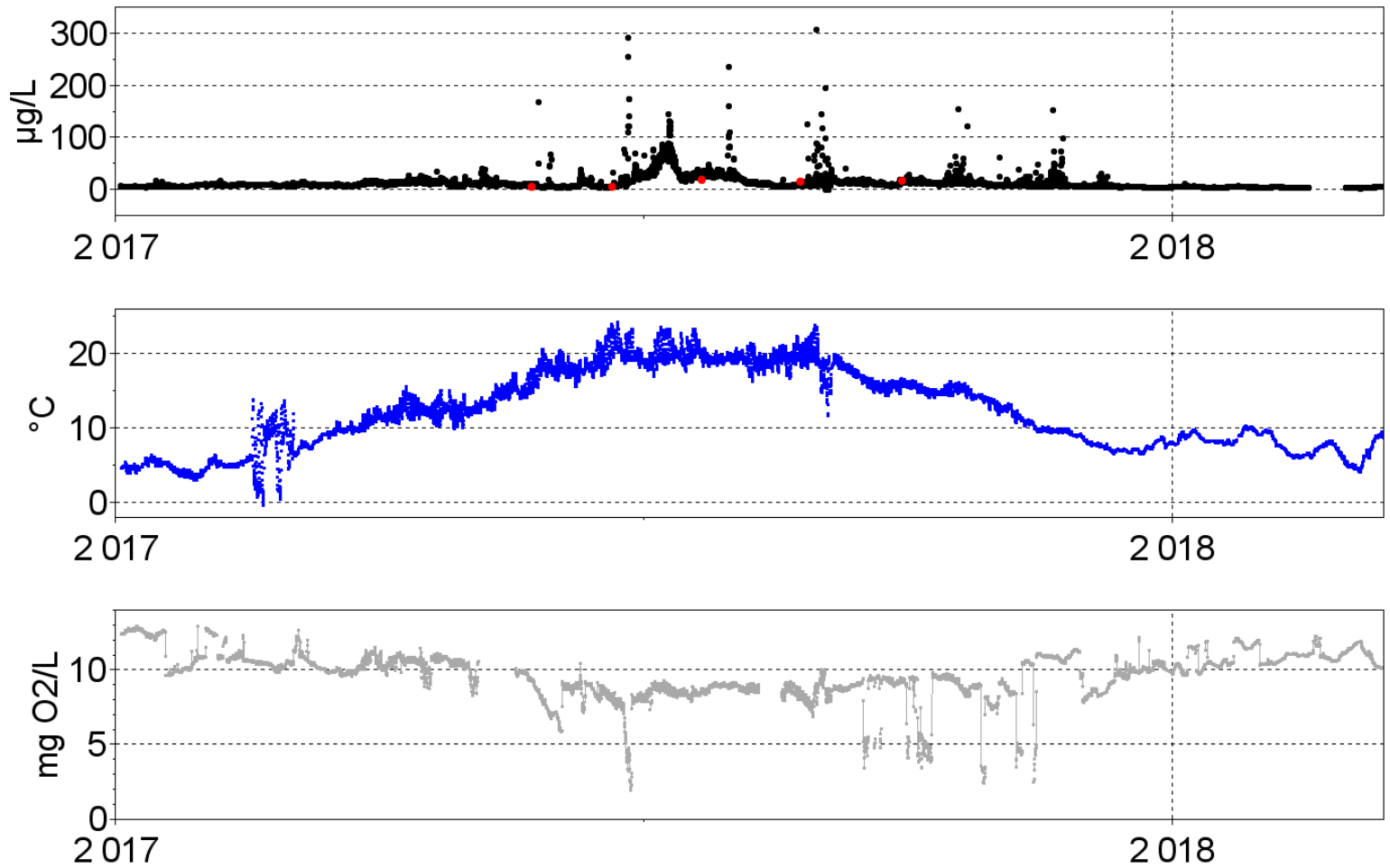

Figure 5. Continuous records of i) chlorophyll a concentration (black dots) compared to punctual measurements associated with phytoplankton and biofilm samples (red dots), ii) water temperature (blue dots) and iii) dissolved oxygen concentration (gray dots) at the downstream station during the 2017 lowflow period. 